\title{
Concurrent observations of atomic iodine, molecular iodine and ultrafine particles in a coastal environment
}

\author{
A. S. Mahajan ${ }^{1}$, M. Sorribas ${ }^{2}$, J. C. Gómez Martín ${ }^{1}$, S. M. MacDonald ${ }^{3}$, M. Gil ${ }^{2}$, J. M. C. Plane ${ }^{3}$, and A. Saiz-Lopez ${ }^{1}$ \\ ${ }^{1}$ Laboratory for Atmospheric and Climate Science (CIAC), CSIC, Toledo, Spain \\ ${ }^{2}$ Atmospheric Research and Instrumentation Branch, National Institute for Aerospace and Technology (INTA), Huelva, Spain \\ ${ }^{3}$ School of Chemistry, University of Leeds, Leeds, UK
}

Received: 3 November 2010 - Published in Atmos. Chem. Phys. Discuss.: 10 November 2010

Revised: 8 March 2011 - Accepted: 13 March 2011 - Published: 17 March 2011

\begin{abstract}
Simultaneous measurements of atomic iodine (I), molecular iodine $\left(\mathrm{I}_{2}\right)$ and ultrafine particles were made at $\mathrm{O}$ Grove, Galicia $\left(42.50^{\circ} \mathrm{N}, 8.87^{\circ} \mathrm{W}\right)$, on the northwest coast of Spain. The observations show a strong tidal signature, and indicate that the most probable sources of reactive iodine species are the exposed macroalgae during low tide. For the first time, $\mathrm{I}_{2}$ and I were concurrently measured revealing a high average $\mathrm{I}_{2} / \mathrm{I}$ ratio of $\sim 32$, which is higher than previously inferred by modelling studies. A 1-dimensional photochemical model is employed to simulate the observations showing that the high $\mathrm{I}_{2} / \mathrm{I}$ ratio can be reproduced in the presence of fast vertical mixing close to the surface, or using an extra chemical loss for I atoms with an unknown species. There is a lack of strong correlation between the $\mathrm{I}_{2} / \mathrm{I}$ and ultrafine particles, indicating that although they both have macroalgal sources, these were not at the same location. The model simulations also suggest that the source of the observed ultrafine particles is likely not very close to the measurement site, in order for the particles to form and grow, but the source for I and $I_{2}$ must be local. Finally, the effect of $\mathrm{NO}_{\mathrm{x}}$ levels on iodine oxides, and the conditions under which iodine particle bursts will be suppressed, are explored.
\end{abstract}

\section{Introduction}

Measurements of reactive iodine species (RIS) in the marine boundary layer (MBL) were initiated by the detection of iodine monoxide (IO) (Alicke et al., 1999), iodine dioxide (OIO) (Allan et al., 2001) and $\mathrm{I}_{2}$ (Saiz-Lopez and Plane, 2004). Recently, the positive detection of I atoms has also been reported (Bale et al., 2008). The above RIS af-

Correspondence to: A. Saiz-Lopez (a.saiz-lopez@ciac.jccm-csic.es) fect the MBL oxidising capacity through depletion of ozone (Chameides and Davis, 1980; Davis et al., 1996; Vogt et al., 1996), and changing the $\mathrm{HO}_{2} / \mathrm{OH}$ and $\mathrm{NO}_{2} / \mathrm{NO}$ balance (McFiggans et al., 2000; Bloss et al., 2005; Saiz-Lopez et al., 2008).

In the coastal marine environment, emissions of $\mathrm{I}_{2}$ from exposed macroalgae, such as Laminaria digitata and Laminaria hyperborea (McFiggans et al., 2004; Ball et al., 2010), have been shown to be the main source of RIS, resulting in an anti-correlation with tidal height (Saiz-Lopez and Plane, 2004; Peters et al., 2005; Mahajan et al., 2009). Measurements of $I_{2}$ have so far been reported at three different mid-latitudinal coastal locations: Mace Head, Ireland (SaizLopez and Plane, 2004; Peters et al., 2005; Huang et al., 2010), California, USA (Finley and Saltzman, 2008) and Roscoff, France (Mahajan et al., 2009; Leigh et al., 2010). However, detection of I atoms has only been reported by Bale et al. (2008) at Mace Head.

Iodine oxides have also been implicated in ultrafine aerosol formation in coastal environments (O'Dowd et al., 2004; McFiggans, 2005). However, iodine-induced ultrafine particle formation has only been reported to occur in two locations so far, i.e. Mace Head, Ireland (O'Dowd et al., 2002; McFiggans et al., 2004) and Roscoff, France (McFiggans et al., 2010) where high particle concentration of $>10^{5}$ particles $\mathrm{cm}^{-3}$ have been observed. The exact mechanism for particle formation is still not well understood, although the latest laboratory results suggest that IO and OIO recombine leading to the formation of $\mathrm{I}_{2} \mathrm{O}_{3}$ and $\mathrm{I}_{2} \mathrm{O}_{4}$, and these two species are directly involved in further polymerisation and growth to ultrafine particles (Saunders et al., 2010).

In this paper we present the first concurrent observations of $\mathrm{I}_{2}$, I and ultrafine particles in a semi-polluted coastal environment, and use these observations to test the current knowledge of iodine chemistry.

Published by Copernicus Publications on behalf of the European Geosciences Union. 


\section{Experimental}

Measurements were made at $\mathrm{O}$ Grove, Galicia $\left(42.50^{\circ} \mathrm{N}\right.$, $8.87^{\circ} \mathrm{W}$ ), on the northwest coast of Spain (Fig. 1) as a part of the Laminariae Emissions in Galicia: observation by fLuorescence and Absorption Spectroscopy (LEGOLAS) field study, from 30 April to 7 May 2010. A macroalgae bed, adjacent to the coast and about $30-50 \mathrm{~m}$ wide was present between $5-10 \mathrm{~m}$ to the north of the measurement site. This area was completely exposed during low tide. Additionally, a similar macroalgal distribution occurs on the south coast of the forested island of Arosa, which is at a distance of approximately $3.5 \mathrm{~km}$ towards the north (Fig. 1). Further to the north, beyond the island of Arosa, the bay concluded at Cabo de Cruz and Rianxo, which were at a distance of $15 \mathrm{~km}$ and $20 \mathrm{~km}$, respectively (Fig. 1), although information about any macroalgal distribution around this part of the bay was not available. The maximum tide height variation observed during the measurement period was $\pm 1.6 \mathrm{~m}$ around average sea level. This was lower than a variation of $\pm 4.5 \mathrm{~m}$ at Roscoff (Mahajan et al., 2009) and $\pm 2.5 \mathrm{~m}$ (Saiz-Lopez and Plane, 2004) at Mace Head during past studies when $I_{2}$ was measured.

\subsection{Resonance and Off-resonance Fluorescence by Lamp Excitation (ROFLEX)}

Concurrent measurements of $I_{2}$ and I were performed using a newly-developed instrument based on the detection of molecular and atomic resonance and off-resonance ultraviolet fluorescence excited by lamp emission. The ROFLEX instrument is described in detail in a companion paper (Gómez Martin et al., 2011), and therefore only a brief description will be given here. The core of the instrument is a low pressure chamber where ambient air is drawn at a rate of approximately $5 \mathrm{slm}$ using a rotary vacuum pump. The iodine atoms and molecules contained in the sampled air are excited by VUV radiation emitted by a radiofrequency discharge iodine lamp. Fluorescence is then collected at right angles by two highly sensitive photon-counting modules. The ambient air flow can also be directed first through an iodine trap for a set time interval before being drawn into the fluorescence chamber, thus allowing a measurement of iodine-free background signal. The iodine trap comprised of an opaque PVC tube in which I atoms are scavenged by ambient ozone in the absence of photolysis, and a Peltier-cooled aluminium box where both $\mathrm{I}$ and $\mathrm{I}_{2}$ are frozen out of the flow. Calibration of the molecular fluorescence signal is achieved in the laboratory by Incoherent Broad Band Cavity-Enhanced Absorption Spectroscopy (IBBCEAS), whereas the atomic signal is calibrated by the photolysis of known amounts of molecular iodine. During the campaign, the average detection limits for I atoms and $\mathrm{I}_{2}$ were 2 and 30 pptv (equivalent to $\mathrm{pmol} \mathrm{mol}^{-1}$ ), respectively, corresponding to an integration time of $10 \mathrm{~min}$ (5 min air sampling +5 min background). Measurement un-

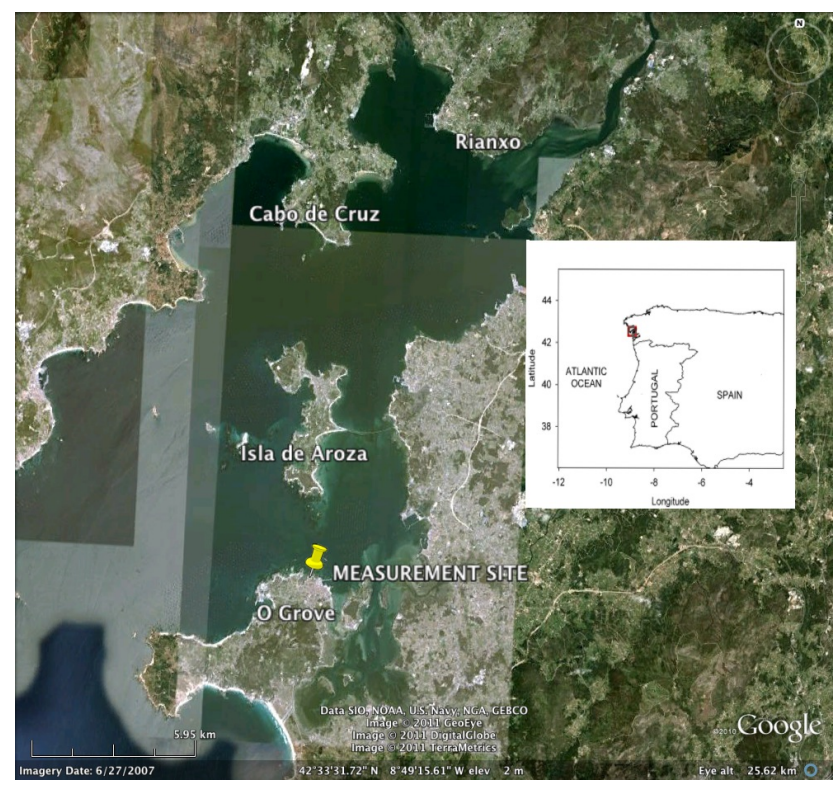

Fig. 1. Location of the measurement site during the LEGOLAS study. There is macroalgae bed $30-50 \mathrm{~m}$ wide adjacent to the site within the inter-tidal zone. A similar bed occurs along the south coast of the island of Isla de Arosa $(3.5 \mathrm{~km})$. Information about macroalgal distribution to the north of the bay near Cabo de Cruz $(15-20 \mathrm{~km})$ was not available. Image from Google maps.

certainties encompass $\pm 2.5 \mathrm{c} \mathrm{s}^{-1}$ (counts per second) precision and $20 \%$ accuracy for $\mathrm{I}$ and $\pm 5 \mathrm{c} \mathrm{s}^{-1}$ precision and $22 \%$ accuracy for $\mathrm{I}_{2}$. The precision of the field measurements was found to be $\sim 3$ times worse than typical laboratory values, reflecting the temperature instability of the lamp described in the companion paper, where the uncertainties related to calibration factors are also discussed in detail (Gómez Martin et al., 2011). The instrument was located on the coast, less than $2 \mathrm{~m}$ away from the high tide line. The measurement height was $1.5 \mathrm{~m}$ above the average sea level.

\subsection{Aerosol instrumentation}

Continuous particle size measurements were simultaneously carried out by two subsystems monitoring different size ranges of dry particles. Particles number size distribution in the 9-407 $\mathrm{nm}$ range was measured using a Scanning Mobility Particle Sizer (SMPS) which was comprised of an Electrostatic Classifier (TSI Model 3080) in conjunction with an Ultrafine Condensation Particle Counter (UCDC) (TSI Model 3776) with $5 \mathrm{~min}$ time resolution. The polydisperse aerosol flow was $0.61 \mathrm{~min}^{-1}$ and the sheath flow was $61 \mathrm{~min}^{-1}$; the latter was dried with silica gel in a closed loop. As a result of the different operational flows of the Electrostatic Classifier $\left(0.61 \mathrm{~min}^{-1}\right)$ and the UCPC $\left(1.51 \mathrm{~min}^{-1}\right)$, an excess flow of $0.91 \mathrm{~min}^{-1}$ was added before the UCPC inlet using a critical orifice to control the flow. Total concentration for particles larger than $3 \mathrm{~nm}$ ( $50 \%$ detection at $3 \mathrm{~nm}$ ) was measured by a 
second UCPC (TSI Model 3776) operating at high flow and with 1 min time resolution. Sample flow for both instruments was dried to $\mathrm{RH}<30 \%$ using a Perma Pure dryer (Perma Pure Inc., Toms River, N) by supplying pressurised dry air to the sheath of the dryer. AIM software (version 8.0.0, TSI INC., St. Paul., MN, USA) was used for data reduction and analysis of the SMPS and UCPC outputs. The accuracy of the system is about $10 \%$. Although the lower size limits for the UCPC are not well defined, the difference in total particle number concentration between the UCPC and SMPS systems is attributed to particles in the size range between 3 and $9 \mathrm{~nm}$ (ultrafine particles). The inlet for the particle measurements was located on top of a shipping container, placed $10 \mathrm{~m}$ away from the shore line. The height of the inlet was about $3.5 \mathrm{~m}$ above the average sea level.

\subsection{Ancillary measurements}

In addition to the above instruments, observations of $\mathrm{O}_{3}(2 \mathrm{~B}$ Technologies, dual beam ozone monitor model number 205), $\mathrm{NO}, \mathrm{NO}_{2}$ (Teledyne API, $400 \mathrm{EU}$ ), co-located but at a height of $3.5 \mathrm{~m}$ and meteorological data at two different heights of $1.5 \mathrm{~m}$ and $3.5 \mathrm{~m}$ (Davis VP2 weather stations) were also available. The $\mathrm{NO}_{\mathrm{x}}$ monitor has a detection limit of $0.4 \mathrm{ppb}$ and a precision of $0.5 \%$ of the reading.

\section{Observations}

The entire time series of measurements made during the LEGOLAS campaign is summarised in Fig. 2. The $\mathrm{I}_{2}$ and I mixing ratios are shown in panels $2 \mathrm{a}$ and $2 \mathrm{~b}$, respectively. Iodine atoms and molecules were observed above the detection limit on 4 days and 1 night, with relatively high values observed on 30 April and 3 May 2010. The highest mixing ratios observed were $10 \pm 5 \mathrm{pptv}$ for I atoms and $350 \pm 100$ pptv for $\mathrm{I}_{2}$, both on 30 April.

Both $I_{2}$ and $I$ also showed an anti-correlation with tidal height during daytime (i.e. higher mixing ratios at low tide), except on 2 May, where no strong anti-correlation was noticeable (Fig. 2a and b). Note that the gaps in the $I_{2}$ and I dataset correspond to periods of rainfall.

Bursts in the total number of ultrafine aerosols, between $3-9 \mathrm{~nm}$ in diameter, were observed only during daytime and low tide on 5 days (Fig. 2c). The highest concentration of ultrafine particles measured was $(1.8 \pm 0.3) \times 10^{4}$ particles $\mathrm{cm}^{-3}$, on 2 May. The background concentration of ultrafine particles was $(1.7 \pm 0.1) \times 10^{3}$ particles $\mathrm{cm}^{-3}$. During low tide, there was no change in the concentrations of aerosol with diameter $>30 \mathrm{~nm}$, indicating that the burst was only in the nucleation mode. The main properties of the nucleation events were calculated using the method described by Birmili et al. (2003). The particle formation rate was determined by dividing the observed increase of concentration within 3-9 $\mathrm{nm}$ by the elapse time,

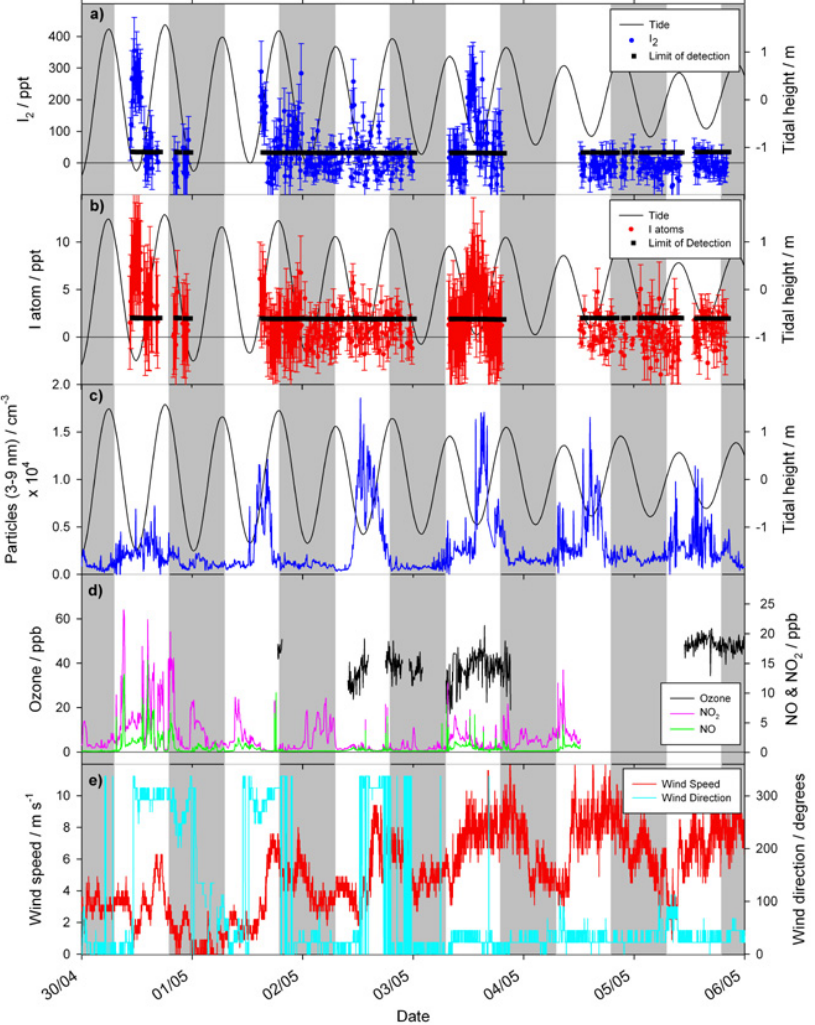

Fig. 2. Time series of measurements made during the LEGOLAS study. Panels (a), (b) and (c) indicate the $\mathrm{I}_{2}$, I and ultrafine particle observations along with the tidal variation. Panel (d) shows the $\mathrm{O}_{3}$, $\mathrm{NO}$ and $\mathrm{NO}_{2}$ observation, while the wind speed and direction is shown in panel (e). Night time is shaded.

and a mean value of $2.6 \pm 0.8 \mathrm{~cm}^{-3} \mathrm{~s}^{-1}$ was obtained. The growth rate was calculated from a linear regression analysis of the mode diameter within $\left[9-D_{\max }\right]$ versus time and it ranged from 1 to $8 \mathrm{~nm} \mathrm{~h}^{-1}$. The SMPS-observed size distributions show the growth of these particles where the maximum diameter ranged from 14-25 nm. A classic "banana" shaped particle growth event was not observed, as shown in Fig. 3. Interestingly, high concentrations of ultrafine particles were also observed even when the $\mathrm{I}_{2}$ and I mixing ratios did not show a large increase, e.g. 2, 4 and 5 May (Fig. 2a, b and c). During the last four days, the integrated observed particle number was correlated to the tidal amplitude (Fig. 2c). In contrast, on 30 April and 1 May, the integrated particle number does not follow the same pattern.

Figure $2 \mathrm{~d}$ shows the $\mathrm{O}_{3}$, $\mathrm{NO}$ and $\mathrm{NO}_{2}$ data throughout the campaign. The $\mathrm{O}_{3}$ mixing ratios were variable with values ranging between 20 and $\sim 60 \mathrm{ppbv}$ (equivalent to $\mathrm{nmol} \mathrm{mol}^{-1}$ ), with an average of about $50 \mathrm{ppbv}$. There are large gaps in the $\mathrm{O}_{3}$ observations due to problems with data capture software. The $\mathrm{NO}$ and $\mathrm{NO}_{2}$ also showed large variability during the campaign with $\mathrm{NO}_{2}$ mixing ratios averaging $\sim 2$ ppbv during daytime low tide conditions. Wind 


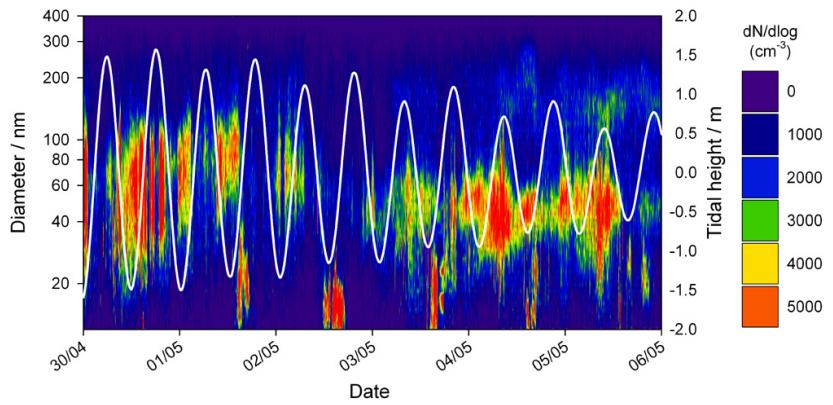

Fig. 3. SMPS observed particle distribution throughout the campaign. Classic "banana" shaped particle growth curves were not observed, with the maximum diameter for particle bursts ranging between 14-25 $\mathrm{nm}$ and the particle bursts were observed only during low tide day time conditions.

speed and direction during the time of observations is shown in Fig. 2e. On average, the wind speed was higher during daytime compared to the night time, and showed significant day-to-day variability throughout the campaign. Low wind speeds of about $1-5 \mathrm{~m} \mathrm{~s}^{-1}$ were observed during low tide on 30 April-2 May, with higher speeds, between about 7-9 m $\mathrm{s}^{-1}$, on 3-5 May. Note that there was no correlation between wind speed and $\mathrm{I}\left(R^{2}=0.095\right), \mathrm{I}_{2}\left(R^{2}=0.063\right)$ or ultrafine particles $\left(R^{2}=0.0032\right)$. However, the wind direction was mostly within a sector of $\pm 30^{\circ}$ northward, which most of the time passed over the island of Arosa (Fig. 2e). Solar radiation data was not available through the campaign, although the conditions were variable with some days being overcast with a near continuous presence of clouds.

\section{Discussion}

The fact that $\mathrm{I}_{2}$, I and ultra-fine particles show a tidal signature on most days when observed above the detection limit indicates that sources for all three are similar. The source is most probably exposure of macroalgae, which induces emission of $I_{2}$, ultimately leading to formation of iodine oxide particles as has been reported in the past (O'Dowd et al., 2002; Saiz-Lopez et al., 2006; McFiggans et al., 2010). As mentioned above, a macroalgal belt, $30-50 \mathrm{~m}$ wide, was observed within the intertidal zone adjacent to the measurement site along the coast. The species Laminaria hyperborea, which is known to be a strong emitter of $\mathrm{I}_{2}$ (Ball et al., 2010) was widely noticeable within this macroalgal belt. The presence of laminaria forests along the Galician coast is well documented (Pérez-Ruzafa et al., 2003). Along with Laminaria hyperborea, Laminaria ochroleuca was also present in large quantities. This species was shown to be an $\mathrm{I}_{2}$ emitter by direct exposure of samples collected from the intertidal pool to the ROFLEX (Gómez Martin et al., 2011). Furthermore, the contribution of additional iodine emissions from the second belt of macroalgae to the north of the measure- ment site at a distance of 3-4 km near the island of Arosa, or a possible third injection point at the other side of the bay at a distance of $15-20 \mathrm{~km}$ cannot be ruled out. The wind direction throughout the campaign indicates that the air mass had passed over both these potential iodine sources. Figure 1 also indicates that there could be several other hotspots of macroalgae towards the north of the measurement site, which suggests a complex emission field. However, no conclusive information to support the presence of such hotspots was available.

An $\mathrm{I}_{2}$ peak mixing ratio of $350 \pm 100 \mathrm{pptv}$ is one of the highest daytime observations reported to date. In the past, studies at other coastal locations have reported a daytime maximum of 25-29 pptv through integrated long-path differential optical absorption spectroscopy (LP-DOAS) measurements at Mace Head (Saiz-Lopez and Plane, 2004; Huang et al., 2010), 115 pptv using in situ measurements at Mace Head (Saiz-Lopez et al., 2006), 87 pptv at Mweenish BayI and 302 pptv Mweenish Bay-II, both close to Mace Head using in situ techniques (Huang et al., 2010), 32 pptv (integrated) and 50 pptv (in situ) at Roscoff (Mahajan et al., 2009; McFiggans et al., 2010), and 3 pptv (in situ) at Scripps Pier, La Jolla, California (Finley and Saltzman, 2008). The peak I atom mixing ratio of $10 \pm 5 \mathrm{pptv}$ is lower than a maximum of 22 pptv reported by Bale et al. (2008) at Mace Head. Throughout the campaign, whenever both $\mathrm{I}_{2}$ and I were measured above the detection limit of the instrument, the average daytime $I_{2} / \mathrm{I}$ ratio ranged between $20-40$, with an average value of 32 . In the past, studies in a similar semi-polluted environment such as Roscoff have indicated much lower $\mathrm{I}_{2} / \mathrm{I}$ ratios, peaking at $\sim 2$ at a height of 4-6 $\mathrm{m}$, where the I atom concentration was modelled from IO observations (Mahajan et al., 2009). A model study by Saiz-Lopez et al. (2006) at Mace Head, which is a cleaner environment with respect to $\mathrm{NO}_{\mathrm{x}}$, predicted an $\mathrm{I}_{2} / \mathrm{I}$ ratio of $\sim 5$ at a height of $5 \mathrm{~m}$ during the daytime; this was later confirmed through I atom measurements made by Bale et al. (2008). The ultrafine particle concentrations observed were lower than previous observations from sites such as Mace Head and Roscoff, where $>10^{5}$ particles $\mathrm{cm}^{-3}$ have been reported. This could be due to a difference in the relative sizes of the seaweed beds, the higher ambient $\mathrm{NO}_{\mathrm{x}}$ mixing ratios, geographical differences, or a combination of these factors, which are discussed in Sects. 4.2 and 4.3 .

On 3 days (2, 4 and 5 May) when ultrafine particle bursts were measured, the gas-phase iodine species did not show an increase (Fig. 2a, b and c). Similarly, on 30 April, I and $\mathrm{I}_{2}$ were elevated during low tide, but the ultrafine particles did not show a large increase over the background concentrations. However, it should be noted that on 30 April, the $\mathrm{NO}_{2}$ and $\mathrm{NO}$ mixing ratios were larger than the rest of the campaign, with an average $\left[\mathrm{NO}_{2}\right]$ of $8 \mathrm{ppbv}$, about 4 times the average on other days. The source of this high $\mathrm{NO}_{\mathrm{x}}$ is most probably relatively fresh pollution as the total aerosol surface area on this day was not significantly higher than the 
campaign average. The dependence of iodine oxides on $\mathrm{NO}_{\mathrm{x}}$ levels is discussed in detail in Sect. 4.3.

The absence of a strong correlation between the gas-phase iodine species and the ultrafine particles indicates that although the sources of both are dependent on tidal height, they are not from the same location.

Hence, there are two outstanding questions regarding the observations: (i) the high $\mathrm{I}_{2}$ :I ratio of $\sim 32$; and (ii) the absence of a strong correlation between ultrafine particles and the measured iodine species.

We use the one dimensional photochemistry and transport Tropospheric Halogen Chemistry Model (THAMO) (SaizLopez et al., 2008) to address these two questions. The iodine chemistry scheme utilised in this work has been updated following Mahajan et al. (2009). The rates of photolysis for all the species are calculated on-line using an explicit two-stream radiation scheme from Thompson (1984). The 1-D model is used with a vertical resolution of $10 \mathrm{~cm}$ up to $20 \mathrm{~m}$, and $5 \mathrm{~m}$ from $2 \mathrm{~m}$ to a boundary layer height of $1 \mathrm{~km}$. The concentrations of all the iodine species, $\mathrm{O}_{3}$ and $\mathrm{NO}_{\mathrm{x}}$ are allowed to vary. The model was initialised with $\left[\mathrm{NO}_{2}\right]=2 \mathrm{ppbv}$ and aerosol surface area $=6 \times 10^{-7} \mathrm{~cm}^{2}$ $\mathrm{cm}^{-3}$ (typical of measurements made during the LEGOLAS campaign). The midday values for $\mathrm{HO}_{2}$ and $\mathrm{OH}$ were set to 6 and $0.1 \mathrm{pptv}$, respectively, according to past observations in the mid-latitudinal MBL (Smith et al., 2006). The modelled $\mathrm{I}_{2} / \mathrm{I}$ ratio is not highly sensitive to $\mathrm{OH}$ and $\mathrm{HO}_{2}$. This is mainly due to the fact that the measurement site was close to the emissions. For example a 2 fold increase in $\mathrm{OH}$ and $\mathrm{HO}_{2}$ mixing ratios results in a $\sim 1 \%$ drop in the $\mathrm{I}_{2}$ mixing ratio by the time the air mass reaches the measurement point, while a 2 fold decrease results in a $\sim 1 \%$ increase The model is allowed to reach steady state for all the other species before iodine chemistry is initialised. Considering that the macroalgal belt was approximately $40 \mathrm{~m}$ in width, an air mass passing over the exposed macroalgae would take $10 \mathrm{~s}$ at $4 \mathrm{~m} \mathrm{~s}^{-1}$ or $5 \mathrm{~s}$ at $8 \mathrm{~m} \mathrm{~s}^{-1}$, which were the average wind speeds on 30 April and 3 May when high mixing ratios of $\mathrm{I}$ and $\mathrm{I}_{2}$ were observed. The model results were found to be sensitive to two parameters: the eddy diffusion coefficient $\left(K_{z}\right)$ and the rates of photolysis, which are discussed in Sect. 4.1.

The high $\mathrm{I}_{2} / \mathrm{I}$ ratio indicates that the source for $\mathrm{I}_{2}$ and $\mathrm{I}$ is local, most probably from the macroalgal bed observed adjacent to the measurement site, due to the short life time of $I_{2}$ ( $6 \mathrm{~s}$ for clear sky conditions). However, the particles would not have had enough time to form within the transport time of up to $10 \mathrm{~s}$ and hence a second injection point is necessary to explain the observed ultrafine particle bursts. This second injection point could be at 3-4 km near the island of Arosa, where a similar macroalgal belt was observed, or further north about $15-20 \mathrm{~km}$ away near the coast of Cabo de Cruz.

\section{1 $I_{2} / I$ ratio}

First, we run the model with a single injection point close to the measurement location to test under what conditions the local emissions can account for the $\mathrm{I}_{2} / \mathrm{I}$ ratio. We consider two possible explanations for the ratio, first, increased vertical mixing of $\mathrm{I}_{2}$ along with reduced photolysis; and second, an extra chemical removal of I atoms.

For the first condition, using only changes to vertical mixing and rates of photolysis, we ran the model for four scenarios. In scenario $1, K_{z}$ is calculated using the wind speed data and a surface roughness length of $1 \mathrm{~cm}$, according to a vertical transport parameterisation by Stull (1988) which is described in Saiz-Lopez et al. (2008). $K_{z}$ ranges from $1 \times 10^{3} \mathrm{~cm}^{2} \mathrm{~s}^{-1}$ close to the surface to $4 \times 10^{4} \mathrm{~cm}^{2} \mathrm{~s}^{-1}$ at $20 \mathrm{~m}$ in the boundary layer. For scenario 1, photolysis rates are calculated for clear sky conditions. In scenario 2, vertical mixing is the same as in scenario 1 , but the photolysis rates are calculated for a $50 \%$ cloudy condition, which represents the filtered effect of a cloud cover and not patchy skies. For scenario 3 , faster vertical mixing is considered close to the surface, with $K_{z}$ ranging from $1 \times 10^{4} \mathrm{~cm}^{2} \mathrm{~s}^{-1}$ close to the surface to $7 \times 10^{4} \mathrm{~cm}^{2} \mathrm{~s}^{-1}$ at $20 \mathrm{~m}$ and clear sky conditions. Finally, in scenario 4 , vertical mixing is the same as scenario 3 along with 50\% cloud cover, to reflect the overcast conditions during some days of the campaign. To reproduce the absolute levels of $\mathrm{I}_{2}$, a flux of $1.2 \times 10^{13}$ molecule $\mathrm{cm}^{-2}$ is required lasting for $10 \mathrm{~s}$ to simulate the passing of an air mass over the macroalgal belt. This necessary flux is higher than previously estimated fluxes, e.g. $1.2 \times 10^{11}$ molecule $\mathrm{cm}^{-2}$ in Roscoff (Mahajan et al., 2009; Leigh et al., 2010).

Figure 4 shows the $I_{2} / \mathrm{I}$ ratio predicted by the model for the above 4 scenarios. The average observed ratio of $\sim 32$ cannot be reproduced for scenario 1,2 or 3 . An increase in vertical mixing helps the emitted $\mathrm{I}_{2}$ to mix up to the measurement height of $1.5 \mathrm{~m}$ (i.e. height of the ROFLEX measurements). To reach a ratio of $\sim 32$, using only an increase in vertical mixing, the $K_{z}$ near the surface needs to be as high as $1 \times 10^{7} \mathrm{~cm}^{2} \mathrm{~s}^{-1}$, meaning that an air mass at the surface would take only $5 \mathrm{~s}$ to rise up to $100 \mathrm{~m}$, which is unrealistic. Therefore, the observed $\mathrm{I}_{2} / \mathrm{I}$ ratio cannot be reproduced using only an increase in vertical mixing. If we consider only a decrease in the rate of photolysis, without an increase in the vertical mixing by changing the cloud cover to even more than scenario 3 to $80 \%$, the model predicts much higher levels of $I_{2}$ close to the source. In this case, a lower flux of $3.0 \times 10^{12}$ molecule $\mathrm{cm}^{-2}$ is necessary to reproduce the absolute levels of $I_{2}(\sim 350 \mathrm{pptv})$ due to the longer lifetime of $I_{2}$. However, the absolute levels of $I$ and the observed ratio are reproduced after $20 \mathrm{~s}$ in the model, which is twice as long as the travel time the air mass would take to reach the measurement site, even under low wind speed conditions. Hence, scenario 4, which reproduces the observations and absolute levels of $I$ and $I_{2}$ after $10 \mathrm{~s}$ of transit time, is a possible scenario to account for the observed $\mathrm{I}_{2} / \mathrm{I}$ ratio. The model 


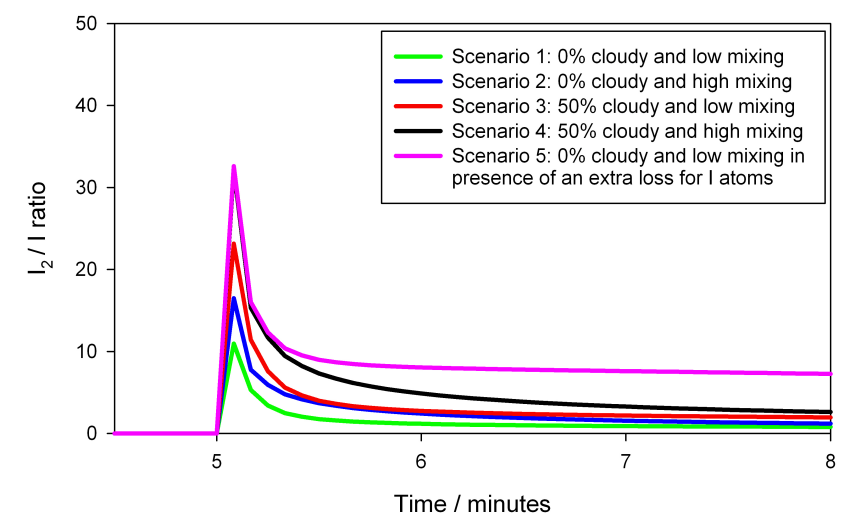

Fig. 4. $I_{2} / I$ ratio change for five scenarios: (1) photolysis is calculated with $0 \%$ cloud cover and slow vertical mixing close to the surface is considered, (2) $0 \%$ cloud cover with faster mixing close to the surface, (3) $50 \%$ cloud cover with slow mixing close to the surface, (4) $50 \%$ cloud cover, with fast mixing close to the surface and (5) $0 \%$ cloud cover with slow mixing close to the surface in the presence of an extra loss for I atoms through reaction with an unknown species.

predicts peak mixing ratios of $322 \mathrm{pptv}$ and $9.7 \mathrm{pptv}$ for $\mathrm{I}_{2}$ and I, respectively, after $10 \mathrm{~s}$, which is in good agreement with the observations (Fig. 2a, b).

Now we consider whether the $\mathrm{I}_{2} / \mathrm{I}$ ratio can be explained using chemical removal of I atoms through reaction with an unknown species. We define scenario 5 , with vertical mixing and photolysis rates calculated similar to scenario 1 , but with an extra species prescribed to react with I atoms with a rate constant of of $1 \times 10^{10} \mathrm{~cm}^{3}$ molecule ${ }^{-1} \mathrm{~s}^{-1}$ (i.e., close to the collision frequency), thereby setting a lower limit to the concentration of this species. This concentration is then tuned to reproduce the observations. In scenario 5 , an $\mathrm{I}_{2}$ flux of $5.4 \times 10^{12}$ molecule $\mathrm{cm}^{-2}(\sim 4.5$ time the flux necessary without any additional loss of I atoms in scenario 4), along with $1.5 \mathrm{ppbv}$ of the unknown species is required to reproduce the $I_{2} / I$ ratio of $\sim 32$ (Fig. 4) along with 335 pptv of $I_{2}$ and $10.5 \mathrm{pptv}$ of $\mathrm{I}$ after $10 \mathrm{~s}$, which are in good agreement with the observations. The identity of an organic species or group of species reacting with I is difficult to assess. Iodine atoms are generally not very reactive with organic compounds (NIST, 2010). They are unable to abstract $\mathrm{H}$ atoms from saturated hydrocarbons, e.g. the reaction of I atoms with a major organic species like methane has a large activation energy of $E_{\mathrm{A}}=140 \mathrm{~kJ} \mathrm{~mol}^{-1}$, which effectively prevents the reaction from proceeding at ambient temperatures. Addition to double bonds of unsaturated hydrocarbons does not seem to be very efficient either (e.g. for I + propylene, $E_{\mathrm{A}}=75 \mathrm{~kJ} \mathrm{~mol}^{-1}$ ), although reaction with longer chain unsaturated hydrocarbons like isoprene have not been studied to date. Reactions with atmospherically relevant haloalkanes, alcohols and aldehydes also have high activation energies. Radical-radical reactions (e.g. with methoxy, methyl peroxy, allyl) are fast, but such radicals are not expected to be at the high concentrations required by the model simulation. Other possible candidates are benzene-1,2 and $-1,3$ diols, which have direct anthropogenic (industrial/combustion) sources and are also oxidation by-products of Poly-Aromatic Hydrocarbons (PAH). These species are water soluble and react readily through aromatic substitution with iodine. There is essentially no atmospheric abundance data available for these species but its unlikely that $1-2$ ppbv mixing ratios suggested in the modelling analysis are realistic. However, the aromatic 1,2 diol group has been identified in humic-like substances (HULIS) which constitute an important fraction of secondary organic aerosol (SOA) (e.g. Graber and Rudich, 2006). Note that the first-order removal rate for such a chemical sink must be approximately twice as fast as the combined rate of reaction of iodine atoms with $\mathrm{O}_{3}$ and $\mathrm{NO}_{\mathrm{x}}$ to explain the observed $\mathrm{I}_{2} / \mathrm{I}$ ratio. Such a chemical sink could possibly result from a combination of reactions with a mixture of organics produced by the interaction of marine air masses, forest emissions from the island of Arosa and anthropogenic pollution.

The modelled $\mathrm{I}_{2} / \mathrm{I}$ ratio in all the scenarios presented above is sensitive to the height of measurements, which is assumed to be $1.5 \mathrm{~m}$ in accord with the instrument inlet height. Changes in surface roughness over the intertidal range could perturb the vertical mixing, particularly up to the height of the instruments. A decrease in height of $0.5 \mathrm{~m}$ causes a $\sim 30 \%$ increase the modelled ratio, while a $0.5 \mathrm{~m}$ increase in height causes a $\sim 15 \%$ decrease in the modelled ratio. However, such an effect of the local topography would be wind speed and direction dependent and a strong correlation with both is not noticed. This suggests that although the effect of local topography cannot be ruled out, it is not the determining variable for the $\mathrm{I}_{2} / \mathrm{I}$ ratio.

\subsection{Ultra-fine particles}

The mechanism of iodine-induced nucleation has been the subject of intense research during the last few years (Burkholder et al., 2004; O'Dowd and Hoffmann, 2005; Saunders and Plane, 2005, 2006; Saunders et al., 2010; Pechtl et al., 2006), but there are still some outstanding questions. Recent laboratory (Saunders et al., 2010) and modelling (Mahajan et al., 2010) studies indicate that $\mathrm{I}_{2} \mathrm{O}_{3}$ and $\mathrm{I}_{2} \mathrm{O}_{4}$ monomers rather than $\mathrm{I}_{2} \mathrm{O}_{5}$ are more likely to be responsible for formation of iodine oxide particles. Thus the sum of $\mathrm{I}_{2} \mathrm{O}_{3}+\mathrm{I}_{2} \mathrm{O}_{4}$ can be considered as a good indicator for the total condensable mass available for iodine induced nucleation.

In scenarios 4 and 5, both of which reproduce the observed $\mathrm{I}_{2} / \mathrm{I}$ ratio after $10 \mathrm{~s}$, the model predicts only $1 \times 10^{-3} \mathrm{pptv}$ and $1 \times 10^{-5} \mathrm{pptv}$, respectively, of $\mathrm{I}_{2} \mathrm{O}_{3}+\mathrm{I}_{2} \mathrm{O}_{4}$ at $3.5 \mathrm{~m}$ (the height of measurements for ultrafine particles during the LEGOLAS study), which is equivalent to only 28 particles $\mathrm{cm}^{-3}$ and 0.28 particles $\mathrm{cm}^{-3}$ of diameter $7 \mathrm{~nm}$, 
which we take to represent the average diameter for iodine oxide particles in a range of 3-9 nm. In this calculation we employ a particle density of $2 \mathrm{~g} \mathrm{~cm}^{-3}$ for hydrated iodine oxide particles (Saunders et al., 2010). This would not be enough to reproduce particle bursts of up to $1.8 \times 10^{4}$ particles $\mathrm{cm}^{-3}$, which were observed during the campaign. In addition, there is a lack of correlation between the ultrafine particles and $\mathrm{I}\left(R^{2}=0.02\right)$ and $\mathrm{I}_{2}\left(R^{2}=0.02\right)$, with the absence of a particle burst in the presence of elevated $I$ and $I_{2}$ on 30 April and the absence of elevated $I$ and $\mathrm{I}_{2}$ in the presence of particle bursts on 2, 4 and 5 May. This indicates that the macroalgal belt close to the measurement site was not the source for the observed ultrafine aerosols but a second injection point, which does not contribute to the I and $\mathrm{I}_{2}$ observations is the source for the particles. If the second macroalgal belt close to the island of Arosa $(\sim 3.5 \mathrm{~km}$ distance, Fig. 1) was the source of these particles, the air mass passing over this source would have reached the measurement site between 8-15 min later depending on the wind speed. If the injection had taken place at the other side of the bay, close to Cabo de Cruz ( $\sim 15 \mathrm{~km}$ distance, Fig. 1), then the air mass would take approximately $60 \mathrm{~min}$ to reach the measurement site.

In scenario 4, where the observations are reproduced using only high $K_{z}$ and low photolysis, the model predicts that $\mathrm{I}_{2} \mathrm{O}_{3}+\mathrm{I}_{2} \mathrm{O}_{4}$ would have been $\sim 22 \mathrm{pptv}$ at the height of measurement $(3.5 \mathrm{~m})$ when the air mass reached the measurement site after $12 \mathrm{~min}$. This corresponds to $\sim 8 \times 10^{5}$ particles $\mathrm{cm}^{-3}$ of diameter $7 \mathrm{~nm}$. This particle number density is much higher than the observed maximum of $1.8 \times 10^{4}$ particles $\mathrm{cm}^{-3}$. In addition, the model also predicts up to $40 \mathrm{pptv}$ of $\mathrm{I}_{2}$ and $36 \mathrm{pptv}$ of I atoms at $1.5 \mathrm{~m}$, which was not observed by the ROFLEX. If we reduce the flux from this second injection point to $2 \times 10^{12}$ molecule $\mathrm{cm}^{-2}$, i.e. about 10 times lower, the model predicts $\sim 2 \times 10^{4}$ particles $\mathrm{cm}^{-3}$ after $12 \mathrm{~min}$, which is in good agreement with the observations. However, the model also predicts about 9 pptv of I atoms, which was not observed by the ROFLEX whenever particle bursts were observed. Hence the $I_{,} I_{2}$ and particle observations cannot be reproduced in scenario 4, even with a lower flux if the second injection point is at the island of Arosa at a distance of $3.5 \mathrm{~km}$. In contrast, if the second injection point in this scenario is in fact at the other end of the bay near Cabo de Cruz, the model predicts $\sim 1 \mathrm{pptv}$ of I atoms, $\sim 1.1 \mathrm{pptv}$ of $\mathrm{I}_{2}$ and $\sim 1$ pptv of $\mathrm{I}_{2} \mathrm{O}_{3}+\mathrm{I}_{2} \mathrm{O}_{4}$ after $60 \mathrm{~min}$. Thus, the $\mathrm{I}$ and $\mathrm{I}_{2}$ would be under the detection limit of the instrument when the air mass from the second injection point reaches the observations site, while 1 pptv of $\mathrm{I}_{2} \mathrm{O}_{3}+\mathrm{I}_{2} \mathrm{O}_{4}$ corresponds to $\sim 2.8 \times 10^{4}$ particles $\mathrm{cm}^{-3}$ of diameter $7 \mathrm{~nm}$, which is in good agreement with the observations. The reduction in the $\mathrm{I}_{2} \mathrm{O}_{3}+\mathrm{I}_{2} \mathrm{O}_{4}$ in this case is due to uptake on background aerosols and dilution in the vertical column, although the vertical dilution is subject to large uncertainties over 1 hour of transport time. The $\mathrm{I}_{2} \mathrm{I}_{2}$ and $\mathrm{I}_{2} \mathrm{O}_{3}+\mathrm{I}_{2} \mathrm{O}_{4}$ distributions in sce- nario 4 using a second injection point at a distance of $15 \mathrm{~km}$ is shown in Fig. 5 (panels a, b and c). Note however that in this scenario, an injection point at the island of Arosa is not considered in order to reproduce the $\mathrm{I} / \mathrm{I}_{2}$ ratio and the particles are produced using an injection point at $15 \mathrm{~km}$, while the ratio is produced using a local source.

In scenario 5, if we consider that the second injection point is at the island of Arosa rather than $15 \mathrm{~km}$ away, the model predicts only $\sim 1 \times 10^{-5} \mathrm{pptv}$ of I, $2 \times 10^{-5} \mathrm{pptv}$ of $\mathrm{I}_{2}$ and only $0.1 \mathrm{pptv}$ of $\mathrm{I}_{2} \mathrm{O}_{3}+\mathrm{I}_{2} \mathrm{O}_{4}$ after $12 \mathrm{~min}$. This corresponds to $\sim 2.8 \times 10^{3}$ particles $\mathrm{cm}^{-3}$, which is much lower than the observed maximum of $1.8 \times 10^{4}$ particles $\mathrm{cm}^{-3}$. If we increase the $\mathrm{I}_{2}$ flux to $1.8 \times 10^{13}$ molecule $\mathrm{cm}^{-2}$, or use the same flux of $1.2 \times 10^{13}$ molecule $\mathrm{cm}^{-2}$ for a longer time of $15 \mathrm{~s}$ (macroalgae emission area $\sim 60 \mathrm{~m}$ wide), the model now predicts about $1 \times 10^{-4} \mathrm{pptv}$ of I, $2 \times 10^{-4} \mathrm{pptv}$ of $\mathrm{I}_{2}$ and 0.6 pptv of $\mathrm{I}_{2} \mathrm{O}_{3}+\mathrm{I}_{2} \mathrm{O}_{4}$ corresponding to $\sim 1.7 \times 10^{4}$ particles $\mathrm{cm}^{-3}$ diameter $7 \mathrm{~nm}$. In addition, the predicted values of I and $I_{2}$ resulting from the injection point $3.5 \mathrm{~km}$ away would be well under the detection limit of the ROFLEX ( 2 pptv for I and 30 pptv for $\mathrm{I}_{2}$ ) and the $\mathrm{I}_{2} / \mathrm{I}$ ratio would be determined only by the local source. The $\mathrm{I}_{2} \mathrm{I}_{2}$ and $\mathrm{I}_{2} \mathrm{O}_{3}+\mathrm{I}_{2} \mathrm{O}_{4}$ vertical distributions for scenario 5 are presented in Fig. 5 (panels $\mathrm{d}$, e and f). It is important to note that, the concentrations of ultrafine particles observed here are much lower than reports from Mace Head and Roscoff (McFiggans et al., 2004, 2010; O'Dowd et al., 2002). The above modelling scenarios, where the ultrafine particles are reproduced indicate that the main difference is most likely (1) the difference in the size of the seaweed beds (for example, in the modelling scenarios we consider that injection of iodine takes place over about $40 \mathrm{~m}$ of exposed algae during low tide. However, in Roscoff, the exposed seaweed bed was about $1 \mathrm{~km}$ long, McFiggans et al., 2010; Mahajan et al., 2009); or (2) the distance of the seaweed beds responsible for the particles from the measurement site, which could result in the air mass reaching the measurement site before the ultrafine particle number peaks, as explained in scenarios 4 and 5. The absence of a classic "banana" growth curves offers some evidence that the measurement site does not receive "fully grown" ultrafine particles but rather air masses where growth is in process. The lack of a banana curve could also be a result of slower growth rates, which cannot be ruled out. Other studies in the past have detailed the conditions under which banana growth curves should be observed (Manninen et al., 2010).

Thus the $\mathrm{I}_{2} / \mathrm{I}$ ratio and ultrafine particle observations can be reproduced in both scenarios by considering different sources for the particles, in scenario 4 at $15 \mathrm{~km}$ distance, while in scenario 5 , at $3.5 \mathrm{~km}$. It should, however, be noted that the number of particles predicted are indicative of the total condensable mass from iodine species and we do not model the particle distribution for a direct comparison with the particle observations.

While no information about macroalgal distribution around Cabo de Cruz was available, a marcroalgal 

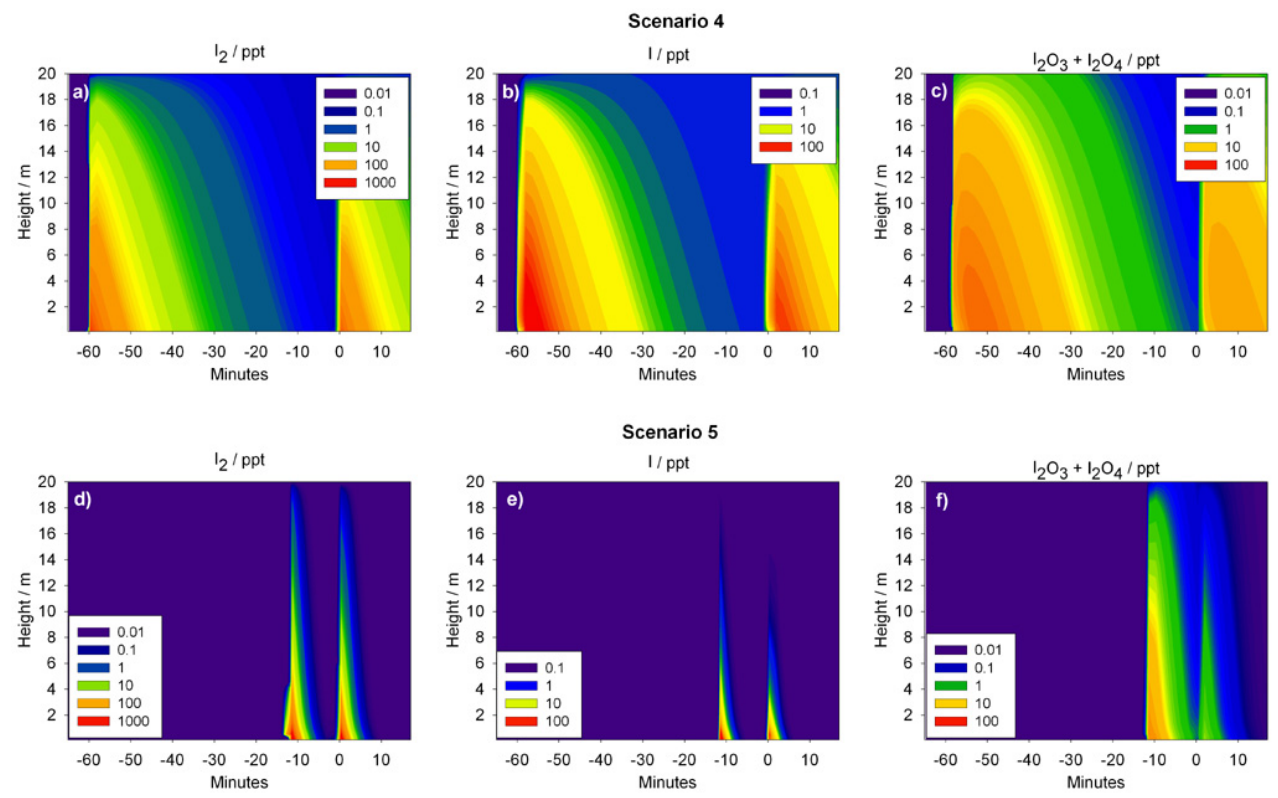

Fig. 5. Vertical distributions of (a) $\mathrm{I}_{2}$, (b) $\mathrm{I}$ and (c) $\mathrm{I}_{2} \mathrm{O}_{3}+\mathrm{I}_{2} \mathrm{O}_{4}$ in scenario 4, with $50 \%$ cloud cover and fast mixing close to the surface and (d) $\mathrm{I}_{2}$, (e) $\mathrm{I}$ and (f) $\mathrm{I}_{2} \mathrm{O}_{3}+\mathrm{I}_{2} \mathrm{O}_{4}$ in scenario 5 with an unknown chemical loss for I atoms. The air mass travelling over the bay arrives at the measurement site at time 0 with a local injection at $-10 \mathrm{~s}$. A second injection point is considered at -60 min for scenario 4 and -12 min for scenario.

distribution around the island of Arosa was noticeable. However, none of the scenarios offer a definitive conclusion on the iodine emission source, or the main causes for the high $\mathrm{I}_{2} / \mathrm{I}$ ratio. It is possible that there was a combination of the above two scenarios with vertical mixing, low photolysis and a reaction with some unknown compound acting simultaneously.

\subsection{Iodine oxide dependence on $\mathrm{NO}_{\mathrm{x}}$}

On 30 April, the highest levels of $\mathrm{I}$ and $\mathrm{I}_{2}$ over the campaign were observed, but there is a distinct lack of a distinctive ultrafine particle burst compared to the other days of measurements. Since the wind speed and wind direction are comparable to days when particle bursts were observed (Fig. 2c and e), the effect of meteorological factors can be discounted. However, on this day the $\mathrm{NO}_{2}$ averages about $8 \mathrm{ppbv}$ during low tide, which is much higher than the average of $2 \mathrm{ppbv}$ during the rest of the campaign, indicating that iodine- $\mathrm{NO}_{\mathrm{x}}$ chemistry is most probably the reason for the absence of ultrafine particle formation on this occasion. Recently, it has been suggested that iodine chemistry is self sustaining in semi-polluted environments due to a mechanism which recycles the reservoir species $\mathrm{IONO}_{2}$ through the reaction $\mathrm{IONO}_{2}+\mathrm{I} \rightarrow$ $\mathrm{I}_{2}+\mathrm{NO}_{3}$ (Mahajan et al., 2009), with a rate constant of $5.5 \times 10^{-11} \mathrm{~cm}^{3}$ molecule ${ }^{-1} \mathrm{~s}^{-1}$ at $290 \mathrm{~K}$ (Kaltsoyannis and Plane, 2008). However, at large $\mathrm{NO}_{2}$ values this reaction is unable to compete with the reaction of $\mathrm{IO}+\mathrm{NO}_{2}+\mathrm{M} \rightarrow$
$\mathrm{IONO}_{2}+\mathrm{M}\left(3.8 \times 10^{-12} \mathrm{~cm}^{3}\right.$ molecule $\mathrm{s}^{-1}$ at $290 \mathrm{~K}$ and 1 atm, Atkinson et al., 2007). In addition, $\mathrm{NO}_{\mathrm{x}}$ also slows down the formation of higher iodine oxides through other reactions such as $\mathrm{I}+\mathrm{NO}_{2}+\mathrm{M} \rightarrow$ $\mathrm{INO}_{2}+\mathrm{M}\left(5.4 \times 10^{-12}\right.$ molecule ${ }^{-1} \mathrm{~s}^{-1}$ at $290 \mathrm{~K}$ and $\left.1 \mathrm{~atm}\right)$, $\mathrm{IO}+\mathrm{NO} \rightarrow \mathrm{I}+\mathrm{NO}_{2}\left(1.95 \times 10^{-11}\right.$ molecule $^{-1} \mathrm{~s}^{-1}$ at $\left.290 \mathrm{~K}\right)$ (Atkinson et al., 2007) and, $\mathrm{OIO}+\mathrm{NO} \rightarrow \mathrm{IO}+\mathrm{NO}_{2}$ $\left(6.7 \times 10^{-12}\right.$ molecule $^{-1} \mathrm{~s}^{-1}$ at $\left.290 \mathrm{~K}\right)$ (Plane et al., 2006).

We now run THAMO under scenarios 4 and 5 with a single injection point while varying only the $\mathrm{NO}_{\mathrm{x}}$ mixing ratio to see under what conditions particle formation would be possible. Figure 6 shows the dependence of $\mathrm{IO}, \mathrm{OIO}, \mathrm{IONO}_{2}$ (at a height of $1.5 \mathrm{~m}$ ), and $\mathrm{I}_{2} \mathrm{O}_{3}+\mathrm{I}_{2} \mathrm{O}_{4}$ (at a height of $3.5 \mathrm{~m}$ ), on the $\mathrm{NO}_{\mathrm{x}}$ levels. This simulation shows that iodine chemistry is strongly influenced by the $\mathrm{NO}_{\mathrm{x}}$ mixing ratio, with only about 0.2 pptv and 0.1 pptv of $\mathrm{I}_{2} \mathrm{O}_{3}+\mathrm{I}_{2} \mathrm{O}_{4}$ predicted after $60 \mathrm{~min}$ in scenario 4 and $12 \mathrm{~min}$ in scenario 5 , respectively, in the presence of $8 \mathrm{ppbv} \mathrm{NO}_{\mathrm{x}}$. This corresponds to only $\sim 5.6 \times 10^{3}$ particles $\mathrm{cm}^{-3}$ and $\sim 2.8 \times 10^{3}$ particles $\mathrm{cm}^{-3}$ of diameter $7 \mathrm{~nm}$, indicating that a distinctive ultrafine particle burst would not be seen in the presence of high $\mathrm{NO}_{\mathrm{x}}$, as was observed on 30 April. Additionally, the observation of elevated levels of $I$ and $I_{2}$ on this day provides further evidence for the $\mathrm{I}$ and $\mathrm{I}_{2}$ observations being a local phenomenon compared to the ultrafine particles, which are most probably emitted further away from the measurement site.

Potential interferences in the ROFLEX observations which could have affected the $\mathrm{I}_{2} / \mathrm{I}$ ratio have been dealt with in detail in the companion paper (Gómez Martin et al., 2011). 

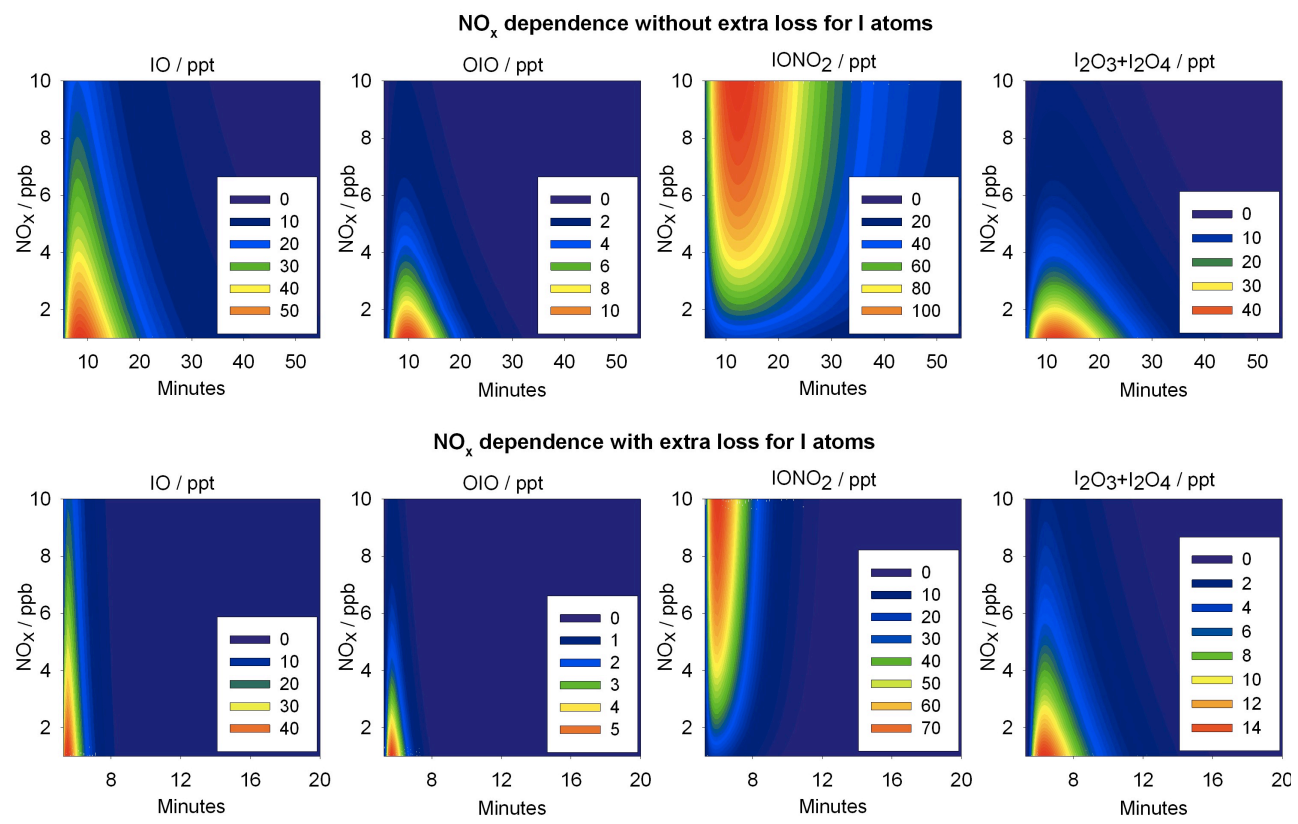

Fig. 6. Dependence of $\mathrm{IO}, \mathrm{OIO}, \mathrm{IONO}_{2}$ and $\mathrm{I}_{2} \mathrm{O}_{3}+\mathrm{I}_{2} \mathrm{O}_{4}$ on $\mathrm{NO}_{\mathrm{x}}$ mixing ratios for scenarios 4 and 5, which both reproduce the observed $\mathrm{I}_{2} / \mathrm{I}$ ratio. Higher $\mathrm{NO}_{\mathrm{x}}$ leads to lower levels of iodine oxides, with most of the iodine converted into $\mathrm{IONO}_{2}$ as the reservoir species. The IO, OIO and $\mathrm{IONO}_{2}$ are at a height of $1.5 \mathrm{~m}$ while the $\mathrm{I}_{2} \mathrm{O}_{3}+\mathrm{I}_{2} \mathrm{O}_{4}$ is at a height of $3.5 \mathrm{~m}$. In the model injection of $\mathrm{I}_{2}$ at a flux of $1.2 \times 10^{13}$ molecule $\mathrm{cm}^{-2}$ takes place after 5 min for $10 \mathrm{~s}$.

Aerosol or water deposition on fluorescence collection optics could also affect the relative sensitivity, although noticeable deposits on optical surfaces were not observed when the fluorescence cell was taken apart after the campaign. Relative intensity changes of the different atomic iodine lines contributing to excitation of $\mathrm{I}$ and $\mathrm{I}_{2}$ could result in a more effective excitation of $I_{2}$ during the campaign compared to the calibration measurements. For instance, a 2 fold loss of sensitivity towards I or enhancement of sensitivity towards $I_{2}$ could bring the $\mathrm{I}_{2} / \mathrm{I}$ ratio to levels explainable without invoking increased vertical mixing or an extra I atom sink. Such changes have not been observed so far in a current long term measurement, where the ratio of sensitivities towards I and $\mathrm{I}_{2}$ stays fairly constant after about a month (within $4 \%$ of the averaged value for a single lamp under the same settings of pressure, temperature and position of the collection and collimating optics, over a period of 20 days, and within $20 \%$ for 4 different lamps of the same batch). However, since lamp aging effects were observed towards the end of the campaign (Gómez Martin et al., 2011), such possibility cannot be entirely ruled out.

\section{Summary and conclusions}

We report the first concurrent observations of $\mathrm{I}, \mathrm{I}_{2}$ and ultrafine particles in a coastal environment, which extend the relatively small available dataset of iodine, especially in semipolluted environments. The complexity of the measurement location is shown by the lack of correlation between $\mathrm{I}_{2} / \mathrm{I}$ and ultrafine particles, indicating that although the source for all three is tidal in nature, it is not at the same location. In addition, a high $\mathrm{I}_{2} / \mathrm{I}$ ratio was observed throughout the campaign, which can be explained by a combination of high vertical mixing close to the surface and lower photolysis, or through the chemical loss of I atoms by reaction with an unknown species, or a combination of the three. The $\mathrm{I}_{2} \mathrm{I}_{2}$ and ultrafine particle observations can be reproduced in the model using two injection points, one very close to the measurement site and a second about $1 \mathrm{~h}$ upwind or $12 \mathrm{~min}$ upwind. Further concurrent measurements of $\mathrm{I}, \mathrm{I}_{2}$ and ultrafine particles, and other RIS, in semi-polluted environments are needed to confirm the high $\mathrm{I}_{2} / \mathrm{I}$ ratio and to improve our understanding of the role of iodine in such chemically complex semi-polluted conditions.

Acknowledgements. The authors thank Rolando Argibai and Marisol Garcia for logistical support during the campaign. We are grateful to T. Ingham for instrumental support and helpful comments. This work was funded by the Spanish Research Council (CSIC) and the Regional Government of Castilla-La-Mancha (FGMACLM).

Edited by: F. Keutsch 


\section{References}

Alicke, B., Hebestreit, K., Stutz, J., and Platt, U.: Iodine oxide in the marine boundary layer, Nature, 397, 572-573, 1999.

Allan, B. J., Plane, J. M. C., and McFiggans, G.: Observations of OIO in the remote marine boundary layer, Geophys. Res. Lett., 28, 1945-1948, 2001.

Atkinson, R., Baulch, D. L., Cox, R. A., Crowley, J. N., Hampson, R. F., Hynes, R. G., Jenkin, M. E., Rossi, M. J., and Troe, J.: Evaluated kinetic and photochemical data for atmospheric chemistry: Volume III - gas phase reactions of inorganic halogens, Atmos. Chem. Phys., 7, 981-1191, doi:10.5194/acp-7-981-2007, 2007.

Bale, C. S. E., Ingham, T., Commane, R., Heard, D. E., and Bloss, W. J.: Novel measurements of atmospheric iodine species by resonance fluorescence, J. Atmos. Chem., 60, 51-70, 2008.

Ball, S. M., Hollingsworth, A. M., Humbles, J., Leblanc, C., Potin, P., and McFiggans, G.: Spectroscopic studies of molecular iodine emitted into the gas phase by seaweed, Atmos. Chem. Phys., 10, 6237-6254, doi:10.5194/acp-10-6237-2010, 2010.

Birmili, W., Berresheim, H., Plass-Dülmer, C., Elste, T., Gilge, S., Wiedensohler, A., and Uhrner, U.: The Hohenpeissenberg aerosol formation experiment (HAFEX): a longterm study including size-resolved aerosol, $\mathrm{H}_{2} \mathrm{SO}_{4}, \mathrm{OH}$, and monoterpenes measurements, Atmos. Chem. Phys., 3, 361-376, doi:10.5194/acp-3-361-2003, 2003.

Bloss, W. J., Lee, J. D., Johnson, G. P., Sommariva, R., Heard, D. E., Saiz-Lopez, A., Plane, J. M. C., McFiggans, G., Coe, H., Flynn, M., Williams, P., Rickard, A. R., and Fleming, Z. L.: Impact of halogen monoxide chemistry upon boundary layer $\mathrm{OH}$ and $\mathrm{HO}_{2}$ concentrations at a coastal site, Geophys. Res. Lett., 32, L06814, doi:10.1029/2004GL022084, 2005.

Burkholder, J. B., Curtius, J., Ravishankara, A. R., and Lovejoy, E. R.: Laboratory studies of the homogeneous nucleation of iodine oxides, Atmos. Chem. Phys., 4, 19-34, doi:10.5194/acp-4-192004, 2004.

Chameides, W. L. and Davis, D.: Iodine: Its Possible Role in Tropospheric Photochemistry, J. Geophys. Res., 85, 7383-7398, 1980.

Davis, D., Crawford, J., Liu, S., McKeen, S., Bandy, A., Thornton, D., Rowland, F., and Blake, D.: Potential impact of iodine on tropospheric levels of ozone and other critical oxidants, J. Geophys. Res.-Atmos., 101, 2135-2147, 1996.

Finley, B. D. and Saltzman, E. S.: Observations of Cl2, Br2, and I2 in coastal marine air, J. Geophys. Res., 113, D21301, doi:10.1029/2008JD010269, 2008.

Gómez Martín, J. C., Blahins, J., Gross, U., Ingham, T., Goddard, A., Mahajan, A. S., Ubelis, A., and Saiz-Lopez, A.: In situ detection of atomic and molecular iodine using Resonance and OffResonance Fluorescence by Lamp Excitation: ROFLEX, Atmos. Meas. Tech., 4, 29-45, doi:10.5194/amt-4-29-2011, 2011.

Graber, E. R. and Rudich, Y.: Atmospheric HULIS: How humiclike are they? A comprehensive and critical review, Atmos. Chem. Phys., 6, 729-753, doi:10.5194/acp-6-729-2006, 2006.

Huang, R.-J., Seitz, K., Buxmann, J., Pöhler, D., Hornsby, K. E., Carpenter, L. J., Platt, U., and Hoffmann, T.: In situ measurements of molecular iodine in the marine boundary layer: the link to macroalgae and the implications for $\mathrm{O}_{3}, \mathrm{IO}$, OIO and $\mathrm{NO}_{\mathrm{x}}$, Atmos. Chem. Phys., 10, 4823-4833, doi:10.5194/acp-10-48232010, 2010

Kaltsoyannis, N. and Plane, J. M. C.: Quantum chemical calcula- tions on a selection of iodine-containing species (IO, OIO, $\mathrm{INO}_{3}$, (IO)(2), $\mathrm{I}_{2} \mathrm{O}_{3}, \mathrm{I}_{2} \mathrm{O}_{4}$ and $\left.\mathrm{I}_{2} \mathrm{O}_{5}\right)$ of importance in the atmosphere, Phys. Chem. Chem. Phys., 10, 1723-1733, 2008.

Leigh, R. J., Ball, S. M., Whitehead, J., Leblanc, C., Shillings, A. J. L., Mahajan, A. S., Oetjen, H., Lee, J. D., Jones, C. E., Dorsey, J. R., Gallagher, M., Jones, R. L., Plane, J. M. C., Potin, P., and McFiggans, G.: Measurements and modelling of molecular iodine emissions, transport and photodestruction in the coastal region around Roscoff, Atmos. Chem. Phys., 10, 11823-11838, doi:10.5194/acp-10-11823-2010, 2010.

Mahajan, A. S., Oetjen, H., Saiz-Lopez, A., Lee, J. D., McFiggans, G. B., and Plane, J. M. C.: Reactive iodine species in a semi-polluted environment, Geophys. Res. Lett., 36, L16803, doi:10.1029/2009GL038018, 2009.

Mahajan, A. S., Plane, J. M. C., Oetjen, H., Mendes, L., Saunders, R. W., Saiz-Lopez, A., Jones, C. E., Carpenter, L. J., and McFiggans, G. B.: Measurement and modelling of tropospheric reactive halogen species over the tropical Atlantic Ocean, Atmos. Chem. Phys., 10, 4611-4624, doi:10.5194/acp-10-46112010, 2010.

Manninen, H. E., Nieminen, T., Asmi, E., Gagné, S., Häkkinen, S., Lehtipalo, K., Aalto, P., Vana, M., Mirme, A., Mirme, S., Hõrrak, U., Plass-Dülmer, C., Stange, G., Kiss, G., Hoffer, A., Töro, N., Moerman, M., Henzing, B., de Leeuw, G., Brinkenberg, M., Kouvarakis, G. N., Bougiatioti, A., Mihalopoulos, N., O’Dowd, C., Ceburnis, D., Arneth, A., Svenningsson, B., Swietlicki, E., Tarozzi, L., Decesari, S., Facchini, M. C., Birmili, W., Sonntag, A., Wiedensohler, A., Boulon, J., Sellegri, K., Laj, P., Gysel, M., Bukowiecki, N., Weingartner, E., Wehrle, G., Laaksonen, A., Hamed, A., Joutsensaari, J., Petäjä, T., Kerminen, V.-M., and Kulmala, M.: EUCAARI ion spectrometer measurements at 12 European sites analysis of new particle formation events, Atmos. Chem. Phys., 10, 7907-7927, doi:10.5194/acp-10-79072010, 2010.

McFiggans, G.: Marine aerosols and iodine emissions, Nature, 433, E13-E13, 2005.

McFiggans, G., Plane, J. M. C., Allan, B. J., Carpenter, L. J., Coe, H., and O'Dowd, C.: A modeling study of iodine chemistry in the marine boundary layer, J. Geophys. Res.-Atmos., 105, 1437114385, 2000.

McFiggans, G., Coe, H., Burgess, R., Allan, J., Cubison, M., Alfarra, M. R., Saunders, R., Saiz-Lopez, A., Plane, J. M. C., Wevill, D., Carpenter, L., Rickard, A. R., and Monks, P. S.: Direct evidence for coastal iodine particles from Laminaria macroalgae - linkage to emissions of molecular iodine, Atmos. Chem. Phys., 4, 701-713, doi:10.5194/acp-4-701-2004, 2004.

McFiggans, G., Bale, C. S. E., Ball, S. M., Beames, J. M., Bloss, W. J., Carpenter, L. J., Dorsey, J., Dunk, R., Flynn, M. J., Furneaux, K. L., Gallagher, M. W., Heard, D. E., Hollingsworth, A. M., Hornsby, K., Ingham, T., Jones, C. E., Jones, R. L., Kramer, L. J., Langridge, J. M., Leblanc, C., LeCrane, J.-P., Lee, J. D., Leigh, R. J., Longley, I., Mahajan, A. S., Monks, P. S., Oetjen, H., Orr-Ewing, A. J., Plane, J. M. C., Potin, P., Shillings, A. J. L., Thomas, F., von Glasow, R., Wada, R., Whalley, L. K., and Whitehead, J. D.: Iodine-mediated coastal particle formation: an overview of the Reactive Halogens in the Marine Boundary Layer (RHaMBLe) Roscoff coastal study, Atmos. Chem. Phys., 10, 2975-2999, doi:10.5194/acp-10-2975-2010, 2010.

NIST: Chemical Kinetics Database on the Web Standard Reference 
Database 17, Version 7.0 (Web Version), National Institute of Standards and Technology (NIST), 2010.

O'Dowd, C. D. and Hoffmann, T.: Coastal new particle formation: A review of the current state-of-the-art, Environ. Chem., 2, 245$255,2005$.

O’Dowd, C. D., Jimenez, J. L., Bahreini, R., Flagan, R. C., Seinfeld, J. H., Hameri, K., Pirjola, L., Kulmala, M., Jennings, S. G., and Hoffmann, T.: Marine aerosol formation from biogenic iodine emissions, Nature, 417, 632-636, 2002.

O'Dowd, C. D., Facchini, M. C., Cavalli, F., Ceburnis, D., Mircea, M., Decesari, S., Fuzzi, S., Yoon, Y. J., and Putaud, J. P.: Biogenically driven organic contribution to marine aerosol, Nature, 431, 676-680, 2004.

Pechtl, S., Lovejoy, E. R., Burkholder, J. B., and von Glasow, R.: Modeling the possible role of iodine oxides in atmospheric new particle formation, Atmos. Chem. Phys., 6, 505523, doi:10.5194/acp-6-505-2006, 2006.

Pérez-Ruzafa, I., Izquierdo, J.-L., Araújo, R., Souza-Pinto, I., Pereira, L., and Bárbara, I.: Distribution maps of marine algae from the Iberian Peninsula and the Balearic Islands. XVII. Laminaria rodriguezii Bornet and aditions to the distribution maps of L. hyperborea (Gunner.) Foslie, L. ochroleuca Bach. Pyl. and L. saccharina (L.) Lamour. (Laminariales, Fucophyceae), Botanica Complutensis, 27, 155-164, 2003.

Peters, C., Pechtl, S., Stutz, J., Hebestreit, K., Hönninger, G., Heumann, K. G., Schwarz, A., Winterlik, J., and Platt, U.: Reactive and organic halogen species in three different European coastal environments, Atmos. Chem. Phys., 5, 3357-3375, doi:10.5194/acp-5-3357-2005, 2005.

Plane, J. M. C., Joseph, D. M., Allan, B. J., Ashworth, S. H., and Francisco, J. S.: An Experimental and Theoretical Study of the Reactions $\mathrm{OIO}+\mathrm{NO}$ and $\mathrm{OIO}+\mathrm{OH}$, J. Phys. Chem., 110, $93-$ 100, 2006.

Saiz-Lopez, A. and Plane, J. M. C.: Novel iodine chemistry in the marine boundary layer, Geophys. Res. Lett., 31, L04112, doi:10.1029/2003GL019215, 2004.
Saiz-Lopez, A., Plane, J. M. C., McFiggans, G., Williams, P. I., Ball, S. M., Bitter, M., Jones, R. L., Hongwei, C., and Hoffmann, T.: Modelling molecular iodine emissions in a coastal marine environment: the link to new particle formation, Atmos. Chem. Phys., 6, 883-895, doi:10.5194/acp-6-883-2006, 2006.

Saiz-Lopez, A., Plane, J. M. C., Mahajan, A. S., Anderson, P. S., Bauguitte, S. J.-B., Jones, A. E., Roscoe, H. K., Salmon, R. A., Bloss, W. J., Lee, J. D., and Heard, D. E.: On the vertical distribution of boundary layer halogens over coastal Antarctica: implications for $\mathrm{O}_{3}, \mathrm{HO}_{\mathrm{x}}, \mathrm{NO}_{\mathrm{x}}$ and the $\mathrm{Hg}$ lifetime, Atmos. Chem. Phys., 8, 887-900, doi:10.5194/acp-8-887-2008, 2008.

Saunders, R. W. and Plane, J. M. C.: Formation pathways and composition of iodine oxide ultra-fine particles, Environ. Chem., 2, 299-303, 2005.

Saunders, R. W. and Plane, J. M. C.: Fractal growth modelling of $\mathrm{I}_{2} \mathrm{O}_{5}$ nanoparticles, J. Aerosol Sci., 37, 1737-1749, 2006.

Saunders, R. W., Kumar, R., Martin, J. C. G. M., Mahajan, A. S., Murray, B. J., and Plane, J. M. C.: Studies of the Formation and Growth of Aerosol from Molecular Iodine Precursor, Zeitschrift für Physikalische Chemie, 224, 1095-1117, doi:10.1524/zpch.2010.6143, 2010.

Smith, S. C., Lee, J. D., Bloss, W. J., Johnson, G. P., Ingham, T., and Heard, D. E.: Concentrations of $\mathrm{OH}$ and $\mathrm{HO}_{2}$ radicals during NAMBLEX: measurements and steady state analysis, Atmos. Chem. Phys., 6, 1435-1453, doi:10.5194/acp-6-1435-2006, 2006.

Stull, R. B.: An introduction to boundary layer meteorology, Kluwer Academic Publishers, London, 1988.

Thompson, A. M.: The effect of clouds on the photolysis rates and ozone formation in the unpolluted troposphere, J. Geophys. Res.Atmos., 89, 1341-1349, 1984.

Vogt, R., Crutzen, P., and Sander, R.: A mechanism for halogen release from sea-salt aerosol in the remote marine boundary layer, Nature, 383, 327-330, 1996. 